\title{
LA FIGURA DEL COMPOSITOR CINEMATOGRÁFICO DURANTE LA DÉCADA DE 1940 EN ESPAÑA
}

THE FIGURE OF THE FILM COMPOSER DURING THE 1940S IN SPAIN

Esther García Soriano

Universidad Complutense de Madrid

garciasorianoesther@gmail.com

http://dx.doi.org/10.12795/AdMIRA.2017.02.04

\section{Resumen:}

La década de 1940 es una de las más prestigiosas, desde el punto de vista de la música cinematográfica. La composición original se había consolidado, dando como resultado grandilocuentes partituras sinfónicas de fuerte influencia decimonónica aderezada por el elemento popular. Dichas pautas, establecidas por el cine norteamericano, son las mismas que se acataron en el cine nacional de aquel período, cuya música ensalzaba las producciones al puro estilo hollywoodiense. En su confección se seguían unas determinadas fases que, mientras los departamentos musicales norteamericanos diversificaban y repartían entre distintos especialistas, los compositores españoles acometían casi por entero. No obstante, dichas dificultades no impidieron que figuras como Jesús García Leoz, Juan Quintero Muñoz, Manuel Parada de la Puente, entre otros, demostraran su maestría y dominio en el campo de la creación musical fílmica. Palabras clave: Cine - Música - España - Posguerra - Compositor

\section{Abstract:}

From a film soundtrack perspective, 1940's is amongst the most significant decades. Original compositions had been consolidated, resulting in grandiose symphonic scores deeply influenced by the nineteenth-century music combined with some popular music element. This pattern, as set out by American cinema, was then also followed by the Spanish film industry, whose music extolled national productions in a pure Hollywood- 
style. While American composers diversified and distributed tasks in different phases and among different specialists, Spanish composers undertook themselves almost entirely all work. However, these burdensome did not prevent artists such as, among others, Jesús García Leoz, Juan Quintero Muñoz or Manuel Parada de la Puente, from showing their expertise and proficiency in the field of film music creation.

Keywords: Cinema - Music - Spain - Postwar - Composer

\section{Introducción}

Apenas pasados unos años tras la invención del cinematógrafo, surgieron los primeros escritos sobre música fílmica. En un primer momento, en forma de pequeños artículos de prensa sin trascendencia sobre cuestiones estéticas y teóricas firmados por aficionados, más tarde insertos en publicaciones especializadas que incluían, asimismo, noticias, biografías, comentarios de partituras con ejemplos musicales, entrevistas a compositores e incluso análisis llevados a cabo por músicos, teóricos y directores de la industria del cine. Fue en Norteamérica a partir de 1909 cuando este compendio literario empezó a tomar vida incrementándose desde los años treinta en adelante. Modern Music, Etude, Musical Quarterly y otros títulos comenzaron a circular en aquel tiempo dando salida a un buen número de reseñas musicales del mundo del celuloide 1. Mientras Milhaud, Antheil, Copland, etc., colaboraban escribiendo para estas publicaciones, otros como Sabayenev o London sacaban al mercado sus trabajos sobre la música en el mundo del cine ${ }^{2}$, a los que años después les seguirían Eisler, Huntley y Levy, entre otros, con sendas investigaciones sobre la materia ${ }^{3}$. La historia y la teoría de la música cinematográfica constituyeron el centro de estudio de estas primeras investigaciones, a las que les siguieron, unas décadas después, trabajos enfocados en otras ramas dentro de esta temática tales como la técnica de composición para cine, el estudio filmográfico de un determinado autor, enciclopedias, entre otros.

En la actualidad, son muy numerosos los estudios sobre diversos aspectos relativos a la música cinematográfica. El protagonismo recae en las bandas sonoras norteamericanas y su historia, teoría, técnica, compositores, etc ${ }^{4}$. Por lo que respecta a la música del cine español en la posguerra, existen monografías, ponencias y artículos, fundamentalmente 
acerca de los creadores. Junto a ellos se encuentran catálogos, volúmenes de carácter histórico y relativos a los géneros fílmicos, sin profundizar en la década de los años cuarenta, que aparece como una más en el desarrollo de la cinematografía nacional. Los exámenes musicales llevados a cabo en una buena parte de estos trabajos se circunscriben a la mera enunciación de los temas, acompañados de una sucinta descripción de su carácter, sin atender a su conformación, como consecuencia de la escasa formación musical de los estudiosos que durante años se han adentrado en este campo. El acercamiento progresivo de la musicología al mismo ha enriquecido ese aspecto con algunos modelos exhaustivos, sobre todo en cuanto a la relación músicaimagen. No obstante, la música para cine español en la posguerra, continúa siendo un campo digno de exploración, dada la riqueza y nivel alcanzados por las composiciones que acompañaron los numerosos filmes realizados durante los años que sucedieron a la Guerra Civil. Es por ello que se decidió estudiar aquel legado musical con los siguientes objetivos: obtener una visión de conjunto en cuanto a sus particularidades en sí y a su vinculación con la naturaleza de las imágenes y determinar los procedimientos empleados por sus creadores en la elaboración de estas composiciones. Se partió de la hipótesis de que, dada la elevada categoría de aquellas obras musicales fílmicas, equiparable a la de sus homólogas norteamericanas del mismo período, el método de realización de las mismas habría de seguir directrices similares o, al menos, aproximadas a las estipuladas por la industria hollywoodiense. Tras el examen de las diversas fuentes, de las que se dará cuenta en las siguientes páginas, se perfiló y desarrolló esta teoría.

\subsection{Apuntes sobre la cinematografía hollywoodiense y española durante la posguerra}

El cine norteamericano de la década de 1940, y más concretamente su música, constituye el principal referente de las bandas sonoras fílmicas españolas del período de posguerra. A continuación, se observan de forma generalizada el contexto y características de ambas producciones, americana y nacional.

Los años cuarenta del pasado siglo XX, considerados una de las épocas de mayor esplendor del cine hollywoodiense, trajo importantes cambios en su historia no solo a nivel estético, con la aparición de nuevos géneros y cineastas, sino que dio paso a una 
nueva concepción de producción fílmica. Desde hacía varias décadas, el séptimo arte resplandecía en manos de las compañías Paramount, MGM, Fox, RKO y Warner Bros., que hicieron de la industria un negocio altamente rentable, monopolizando todos los aspectos de la creación cinematográfica -selección del guion, técnicos, actores y resto del equipo-, hasta su proyección en determinadas salas. Las numerosas películas resultantes exhibían el sello distintivo de cada estudio al que pertenecía, por contrato, toda una plantilla de trabajadores y artistas. Se gestó así un Star System del que formaban parte celebridades como Joan Crawford, Clark Gable, Greta Garbo, Spencer Tracy, Bette Davis, Judy Garland, entre muchas otras, a las que se les aseguró un salario y un perfil público excelso, diseñado a imagen y semejanza de una deidad clásica. Con el objeto de mantener un espectáculo que hiciera las delicias del público y de los inversores, se llevó a cabo una masiva realización serial de películas dentro de un amplio abanico de temáticas.

El inicio de la II Guerra Mundial y su consiguiente posguerra alteraron significativamente esta perspectiva. Las marcas registradas de cada estudio fueron desmanteladas con la cancelación de los contratos que ligaban durante años a los trabajadores con sus productoras. El cine, como medio de difusión, se convirtió en una destacada herramienta propagandística del conflicto bélico, incluso una vez finalizado este, empleado en ocasiones como mero fondo de argumentos de suspense y aventuras. Las cintas Casablanca (Casablanca, 1942, Michael Curtiz), Sabotaje (Saboteur, 1942, Alfred Hitchcock) y Objetivo Birmania (Objetic Burma!, 1945, Raoul Walsh), entre otras, son una buena prueba de ello. En medio de este oscuro ambiente surgieron obras excepcionales y novedosas como Ciudadano Kane (Citizen Kane, 1941, Orson Welles). La comedia continuó dando frutos, aunque en menor medida que en años pretéritos, con títulos como Historias de Filadelfia (The Philadelphia Story, 1940, George Cukor) o Arsénico por compasión (Arsenic and Old Lace, 1944, Frank Capra). Pero el género por excelencia de este período fue el cine negro o film noir, procedente de la novela negra de la década de 1930. El halcón maltés (The Maltese Falcon, 1941, John Huston) constituye el primer ejemplo y el más representativo de una larga serie de largometrajes cuyos personajes escabrosos se encontraban inmersos en una atmósfera plena de intriga y complot, tal y como sucedía en las películas de gánsteres precedentes. Laura (Laura, 1944, Otto Preminger), La mujer del cuadro (The Woman in the Window, 1944, Fritz 
Lang), Gilda (Gilda, 1946, Charles Vidor), El sueño eterno (The Big Sleep, 1946, Howard Hawks), La senda tenebrosa (Dark Passage, 1947, Delmes Daves), Voces de muerte (Sorry, Wrong Number, 1948, Anatole Litvak), El abrazo de la muerte (Criss Cross, 1949, Robert Siodmak), son solo algunos de los muchos títulos donde el suspense constituía el corazón de la trama.

Por otra parte, la cinematografía española no pasaba por su mejor momento. Diego Galán se refiere a ella como "la más extravagante, enloquecida, curiosa y patética de su propia historia" (Galán, 2000: 113). Las condiciones del país tras la guerra y el control que el general Franco ejerció sobre esta industria determinaron sus características. El cine, como medio propagandístico de la ideología franquista, estuvo sujeto a manipulación por parte del Régimen. Guiones, rodajes, exhibiciones y exportaciones se sometieron a la inspección censora, y algunas medidas de protección otorgadas, como las licencias de doblaje, llevaron a la producción en masa de filmes de mala calidad con el único objetivo de importar películas extranjeras. Fruto del aislamiento que sufría el país, se desconocían en profundidad las cinematografías extranjeras y los profesionales contaban con escasa formación, así como una baja infraestructura para desarrollar su trabajo. No obstante, las buenas producciones también tuvieron su espacio en aquella época.

La productora CIFESA compensaba la precariedad empresarial imperante, equiparándose a los estudios hollywoodienses cuyas películas se desarrollaban en grandes salones burgueses y ricos espacios de ambientes históricos, interpretadas por los actores populares del momento como Amparo Rivelles, Luchy Soto, Guadalupe Muñoz Sampedro, Josita Hernán, Alfredo Mayo, Rafael Durán, Fernando FernánGómez y muchos otros que constituían el Star System español.

Un reducido grupo de directores consiguió lo más notable de esta cinematografía en aquel período, dentro de un amplio abanico de géneros. Entre ellos cabe citar a José Luis Sáenz de Heredia, cuya versatilidad y desenvoltura quedaron plasmadas en títulos como Raza (1941), El escándalo (1943), El destino se disculpa (1945) y La mies es mucha (1949). Edgar Neville destacó por su creatividad, imaginación y criterio personal dejando obras como La torre de los siete jorobados (1944), Domingo de carnaval (1945), La vida en un hilo (1945), El crimen de la calle Bordadores (1946), Nada (1947) y El último caballo (1950). Rafael Gil firmó importantes éxitos tanto en la 
comedia, el cine religioso, histórico y literario, como El hombre que se quiso matar (1942), Viaje sin destino (1942), Huella de luz (1942), Eloísa está debajo de un almendro (1943), El fantasma y doña Juanita (1944), El clavo (1944), La pródiga (1946) y La fe (1947). Juan de Orduña, uno de los directores del cine oficial, alcanzó la fama con el cine histórico, aunque también logró destacados resultados en la comedia y el melodrama. A él se deben largometrajes como Deliciosamente tontos (1943), Rosas de otoño (1943), Ella, él y sus millones (1944), Un drama nuevo (1946) у Locura de amor (1948). La disconformidad que mostraba Carlos Serrano de Osma respecto a las directrices del cine oficial, se vio plasmada en innovadoras producciones como Abel Sánchez (1946) y La sirena negra (1947). Ignacio F. Iquino, adscrito al cine comercial, fue el máximo representante de la cinematografía catalana con títulos como El difunto es un vivo (1941), Boda accidentada (1942) y El tambor del Bruch (1948). También fueron destacados de este momento Antonio Román, Antonio del Amo, Luis Lucia, Luis Marquina y Eduardo García Maroto, entre otros.

\subsection{Consolidación de la creación musical cinematográfica en la posguerra.}

\section{Compositores españoles y obras}

Entre los muchos elementos fílmicos enriquecedores de las producciones de la década de 1940, tanto hollywoodienses como españolas, se encuentra la música, que vivía en aquel período una de sus mejores épocas por distintas razones. No solo había solventado los problemas técnicos del pasado producidos tras la llegada de la sonorización, relacionados con la velocidad de grabación, sincronización, micrófonos, etc., sino que tras muchos años restringida a lo que las piezas de biblioteca preexistentes y mundialmente conocidas podían ofrecer, consiguió perfeccionar sus competencias como elemento expresivo del filme gracias al afianzamiento de la composición original, que recayó en manos de los mejores profesionales del medio.

En los estudios hollywoodienses, junto a los veteranos se situó un importante elenco de compositores europeos cuya formación académica, en diferentes conservatorios y escuelas, se vio reflejada en las partituras que exaltaron la emoción impresa en aquellos filmes. Entre las figuras más destacadas se encuentra Max Steiner, especializado en el melodrama y el cine negro, con partituras como las pertenecientes a La extraña 
pasajera (Now, Voyager, 1942, Irving Rapper), Casablanca (Casablanca, 1943, Michael Curtiz), El sueño eterno (The Big Sleep, 1946, Howard Hawks) o Cayo Largo (Key Largo, 1948, John Huston). Franz Waxman firmó la música de varios filmes bélicos y de suspense, tales como Destino Tokyo (Destination Tokyo, 1943, Delmer Daves), Objetivo Birmania (Objective, Burma!, 1945, Raoul Walsh) o Amor que mata (Possessed, 1947, Curtis Bernhardt). Alfred Newman colaboró en proyectos cinematográficos de índole social, psicológico y religioso, entre otros, reflejado en sus obras para Las uvas de la ira (The Grapes of Wrath, 1940, John Ford), Nido de víboras (The Snake Pit, 1948, Anatole Litvak), Sangre y arena (Blood and Sand, 1941, Rouben Mamoulian) o La canción de Bernadette (The Song of Bernadette, 1943, Henry King). David Raksin abandonó su anonimato tras poner música al emblemático filme Laura (Laura, 1944, Otto Preminger). Bernard Herrmann, al igual que Raksin, lanzó su carrera gracias a la composición que firmó para Ciudadano Kane (Citizen Kane, 1941, Orson Welles). Miklós Rózsa elaboró destacados trabajos para El libro de la selva (Jungle Book, 1942, Zoltan Korda), La carta (The Letter, 1940, William Wyler) o Perdición (Double Indemnity, 1944, Billy Wilder). Hugo Friedhofer compuso la música para La mujer del cuadro (The Woman in the Window, 1945, Fritz Lang) o Los mejores años de nuestra vida (The Best Years of Our Lives, 1946, William Wyler) y a Victor Young se le deben las creaciones para Por quién doblan las campanas (For Whom the Bells Tolls, 1943, Sam Wood) o Cartas a mi amada (Love Letters, 1945, William Dieterle), entre otras.

El estilo forjado por los músicos hollywoodienses fue el referente primordial para los compositores del cine español de la posguerra, quienes tomaron a aquellas ilustres figuras como sus maestros de creación musical fílmica. Se trata de una larga lista de artistas que, en un momento $\mathrm{u}$ otro, participaron en el cine. No obstante, los que hicieron de esta industria su principal medio de vida dedicándose casi en exclusiva a la misma, constituyen un grupo reducido. A la cabeza del mismo se sitúa Jesús García Leoz ${ }^{5}$ con una filmografía en esta década que sobrepasa las sesenta películas. Su trayectoria y la de Juan Quintero Muñoz ${ }^{6}$ son bastante afines. Ambos emprendieron su profesión como pianistas del cine mudo. Más tarde, dentro de la composición, cultivaron todo tipo de géneros, con preponderancia del drama y la comedia. Su eficiencia y resolución hicieron que los directores se los disputaran. 
García Leoz trabajó con más de una treintena de cineastas entre los que destacan Ladislao Vajda, Antonio de Obregón, Antonio del Amo, Arturo Ruiz-Castillo, Ramón Barreiro y Carlos Serrano de Osma, para los que realizó la música de Tarjeta de visita (1944) de Antonio de Obregón, El testamento del virrey (1944) de Vajda, La sirena negra (1947) de Serrano de Osma, El pirata Bocanegra (1946) de Ramón Barreiro, La manigua sin dios (1948) de Ruiz-Castillo, Noventa minutos (1949) de Antonio del Amo, y la de muchos otros largometrajes. En palabras de Juan Mariné: "Llegó un momento en que él era el mejor, era el gran dios de las músicas en las películas españolas" (Roldán, 2004: 374). Por otra parte, Quintero Muñoz se puso a las órdenes de Luis Lucia, Eusebio Fernández Ardavín, Jerónimo Mihura y otros. Pero fueron dos maestros los que impregnaron sus realizaciones con su estilo: Juan de Orduña y Rafael Gil. Fruto de su estrecha colaboración con ambos nacieron las bandas sonoras para Deliciosamente tontos (1943), Rosas de otoño (1943), Tuvo la culpa Adán (1944), Ella, él y sus millones (1944) y Un drama nuevo (1946), a las órdenes de Juan de Orduña; Huella de luz (1942), Eloísa está debajo de un almendro (1943), El clavo (1944), El fantasma y doña Juanita (1944) y La pródiga (1946), junto a Rafael Gil. Como García Leoz, "se convirtió en el amo de la música de Madrid” (Roldán, 2004: 399).

La estrecha unión entre creador y director que marcó la carrera de Quintero al lado de Juan de Orduña y Rafael Gil, se presenta asimismo en el currículum de Manuel Parada de la Puente ${ }^{7}$ junto a su amigo, el realizador José Luis Sáenz de Heredia, para quien elaboró mayor número de trabajos, entre los que se encuentran El escándalo (1943), El destino se disculpa (1945), Mariona Rebull (1947) y La mies es mucha (1949), entre otros. Uno de ellos, Raza (1941), le convirtió en el principal compositor del Régimen franquista. Su destreza para escribir temas heroicos y de aire militar le llevó a ilustrar tres largometrajes más dentro del género: Los últimos de Filipinas (1945) de Antonio Román, Alhucemas (1947) de José López Rubio y Paz (1949), de J. D. Morales. Otro hecho significativo que le reportó popularidad fue la invención de la fanfarria introductoria y de los fondos musicales del Noticiario Cinematográfico Español (NODO).

Frente a las partituras marciales de Parada, se encuentran las pertenecientes a Malvaloca (1942) de Luis Marquina, Una chica de opereta (1943) de Ramón Quadreny, y La boda de Quinita Flores (1943) de Gonzalo Pardo Delgrás, todas de José Ruiz de Azagra ${ }^{8}$, 
especializado en la comedia, con una filmografía que no sobrepasa las veinte películas en esta época. Como él, Joan Duran i Alemany ${ }^{9}$ también sobresalió en el género al que dedicó la mayor parte de su trabajo en aquel tiempo, junto a directores de la talla de Miguel Iglesias y Alejandro Ulloa, entre otros. No obstante, su colaboración más destacada en este período fue con Ricardo Gascón e Ignacio F. Iquino, para quienes compuso las bandas sonoras de numerosos filmes, tales como Boda accidentada (1942) y El hombre de los muñecos (1943) ambos de Iquino, Un ladrón de guante blanco (1945) y Ha entrado un ladrón (1949), de Gascón, a las que colmó de melodías modernas influenciadas por el jazz. Él mismo definía este estilo así: “...no es sino música internacional, porque es la que gusta a todas las multitudes e impresiona grandemente el oído cuando está tratada con modulaciones y gran masa de cuerda" (A, 1943). Según el testimonio de su hijo Antoni Duran, su gran dedicación al género le valió el apelativo de "el Gershwin español"10 , autor "al que adoraba" y que ejerció gran influencia en sus creaciones ${ }^{11}$. Además de la música incidental, firmó gran número de canciones interpretadas en las comedias cinematográficas por artistas de la talla de Rina Celi. Títulos como Pu-pu-pi-du, perteneciente a El difunto es un vivo (1941), y Arrullo de amor interpretado en El pobre rico (1942), ambos filmes de Ignacio F. Iquino, traspasaron la pantalla grande convirtiéndose en éxitos discográficos.

El último grupo de nombres destacados en la música de cine de posguerra está constituido por Manuel López-Quiroga, que trabajó en unas treinta películas, seguido de Ramón Ferrés i Mussolas y José Muñoz Molleda, con poco más de veinte partituras cinematográficas cada uno.

Así como el jazz distinguió la producción de Duran i Alemany, la de Manuel LópezQuiroga $^{12}$ se vio monopolizada por el folclore andaluz, con escasas incursiones de las melodías madrileñas y los ritmos castellanos. Su participación en el cine se dio tanto a nivel de compositor absoluto de la banda sonora, como de colaborador en la realización de canciones, junto a los letristas Rafael de León y Antonio Quintero, con los que participó en numerosos filmes tales como Pepe Conde (1941) de López Rubio, Oro y marfil (1947) de Pardo Delgrás y La Cigarra (1948) de Florián Rey. Concedió un gran espacio a la música de pantalla, colmando los largometrajes de números y canciones para el lucimiento de grandes artista de la copla como Imperio Argentina, Pastora Imperio, Juanita Reina, entre otras, no solo a través del musical sino de todos los 
géneros en los que participó: de aventuras, bélico, dramático y cómico, este último, uno de los más destacados en su carrera fílmica.

Si algún autor estableció un tándem artístico con un cineasta en esta época ese fue Ramón Ferrés i Mussolas ${ }^{13}$, cuyo recorrido cinematográfico se ligó al de su hijo, el productor y director Ignacio F. Iquino, casi desde sus inicios. Comenzó a sobresalir en la segunda mitad de la década de los años cuarenta, firmando alrededor de dos o tres bandas sonoras anuales. Abordó los géneros dramático, policíaco, bélico, y de animación, incidiendo sobre todo en la comedia, para la que creó partituras como las de Fin de curso (1943) y Turbante blanco (1944), ambas películas de Iquino, así como las de Mi adorado Juan (1949) de Julio Salvador y Despertó su corazón (1949) de Jerónimo Mihura. Fiel a la productora de su hijo, Emisora Films, continuó en el cine mientras esta estuvo en activo, tras lo cual abandonó el medio, exceptuando alguna puntual intervención.

El último nombre que completa este apartado es José Muñoz Molleda ${ }^{14}$. Su estética tradicional y "antivanguardista" hicieron de él un músico del agrado del Régimen franquista y, por tanto, una figura indispensable para el cine más destacado de la época. Importantes directores como Antonio Román y Julio Fleischner depositaron en él su confianza, no obstante, la mayor parte de su labor la desempeñó a las órdenes de Edgar Neville, con quien trabajó en las películas Correo de Indias (1942), Café de París (1943), Domingo de carnaval (1945), Nada (1947) y El último caballo (1950), entre otras.

Tras estos maestros de la música cinematográfica se sitúa un extenso listado de compositores, algunos de ellos de alto rango, cuya participación en el cine español de esta época fue tan solo esporádica, con nueve bandas sonoras o menos en el período investigado. Se sitúan en esta categoría Jesús Guridi, Emilio Lehmberg, Fernando Moraleda, Modesto Rebollo, Pascual Godes, Pedro Braña, Joaquín Turina, Rafael Martínez Valls, Salvador Ruiz de Luna, y un largo etcétera.

\subsection{Delimitación del estudio}

La música cinematográfica española de la década de 1940 comprende un vasto listado de compositores, la mayoría vinculados al séptimo arte por una, dos o tres películas para las que crearon sus partituras correspondientes. Frente a este extenso grupo de artistas, 
se sitúa aquel constituido por un reducido número de figuras fielmente comprometidas con el cine, al que se dedicaron casi en exclusiva convirtiéndolo en su principal fuente de ingresos. Dado su protagonismo, relevancia y notoria filmografía de la que extraer información, frente a aquellos con modestas o incluso ignoradas incursiones en el medio, el presente estudio se centralizó en dichos especialistas. Jesús García Leoz, Manuel Parada de la Puente y Juan Quintero Muñoz son, entre otros, algunos de los más destacados. Todos ellos intervinieron en la composición musical para cortometrajes, no obstante, la mayoría de sus creaciones estuvieron destinadas a producciones de larga duración, por lo que se delimitó el campo de estudio hacia dicho legado. Una vez definida el área a investigar, y examinada la bibliografía general existente sobre música cinematográfica, el primer paso fue el establecimiento del estado de la cuestión referente a la música de cine español durante los años cuarenta.

El presente artículo aborda, principalmente, la figura del compositor de cine en España en la etapa mencionada y su trabajo, en cuanto a las diversas fases que se llevaban a cabo en la conformación de una partitura fílmica nacional en aquel momento. Como introducción se abordan las características generales del cine español en la posguerra, así como de su música cinematográfica, tomando como punto de referencia Hollywood, cuyo influjo fue decisivo en el campo de la creación musical fílmica.

\section{Metodología y resultados}

-Revisión teórico-bibliográfica

Frente a la amplia y variada muestra bibliográfica que existe sobre todo en relación al ámbito norteamericano, la vinculada a la música cinematográfica nacional disminuye considerablemente, y aún más dentro del período objeto de estudio. Su consulta y clasificación en función de su contenido, permitió determinar cuáles son los ámbitos más abordados, así como aquellos que gozan de un menor examen, y el tipo de aproximación acometida en cada caso. La mayoría se restringe en gran parte a ponencias realizadas en diversos congresos y artículos en publicaciones varias ${ }^{15}$. Junto a estos, existen trabajos monográficos que exploran las biografías, carreras artísticas y analizan algunas de las creaciones de estos músicos ${ }^{16}$. La biofilmografía de los creadores españoles vinculados al cine también aparece recogida en guías, diccionarios y enciclopedias ${ }^{17}$. Por otra parte, las obras de carácter histórico que engloban las 
diferentes épocas con sus particularidades estilísticas, autores y obras, son $\operatorname{minoritarias}^{18}$. Existen investigaciones relativas a la música popular fílmica, que se adentran en géneros como el jazz, el flamenco o la zarzuela ${ }^{19}$. La prensa cinematográfica de la época, ofrece testimonios y noticias sobre los compositores españoles de posguerra ${ }^{20}$. En cuanto a los abundantes recursos web, centrados en su mayoría en la vida y obra de los compositores, presentan, muchos de ellos, errores frecuentes y lagunas ${ }^{21}$.

-Selección de compositores y obras

Analizadas todas las fuentes descritas y extraída la información relativa a obras y creadores de aquel período, el estudio se circunscribió a aquellos que hicieron del cine su medio de vida, compilando una extensa filmografía de la que poder extraer datos y conclusiones. Dichos maestros fueron: Jesús García Leoz, Juan Quintero Muñoz, Manuel Parada de la Puente, José Ruiz de Azagra, Joan Duran i Alemany, José Muñoz Molleda, Ramón Ferrés i Mussolas y Manuel López-Quiroga. Aunque el presente artículo se centra en la figura del compositor cinematográfico en España en la década de 1940, se consideró oportuno realizar una visión panorámica de las características generales de su legado en aquellos años como complemento a la investigación, sin la intención de profundizar en su examen. Por ello, la elección de títulos se limitó a unos pocos de cada autor que, en mayor o menor medida, reunieran las siguientes características: largometrajes considerados representativos por los especialistas en cinematografía, de fácil acceso a su visionado, conservados en buen estado, cuyas partituras correspondientes aún existieran, catalogados dentro de un amplio espectro de géneros fílmicos y cuya distribución en número resultara equilibrada a lo largo de la década (véase tabla 1)

\begin{tabular}{|l|c|l|l|l|}
\hline \multicolumn{1}{|c|}{ PELÍCULA } & AÑO & \multicolumn{1}{|c|}{ DIRECTOR } & GÉNERO & \multicolumn{1}{c|}{ COMPOSITOR } \\
\hline Barrio & 1947 & Ladislao Vajda & Drama & Jesús García Leoz \\
\hline Boda en el infierno & 1942 & Antonio Román & Drama & José Muñoz Molleda \\
\hline Canelita en rama & 1942 & $\begin{array}{l}\text { Eduardo García } \\
\text { Maroto }\end{array}$ & Musical & $\begin{array}{l}\text { Manuel López- } \\
\text { Quiroga }\end{array}$ \\
\hline Cinco lobitos & 1945 & Ladislao Vajda & Comedia & Jesús García Leoz \\
\hline $\begin{array}{l}\text { Difunto es un vivo, } \\
\text { El }\end{array}$ & 1941 & Ignacio F. Iquino & Comedia & $\begin{array}{l}\text { José Ruiz de Azagra, } \\
\text { Joan Duran i Alemany }\end{array}$ \\
\hline $\begin{array}{l}\text { Domingo de } \\
\text { carnaval }\end{array}$ & 1945 & Edgar Neville & Drama & José Muñoz Molleda \\
\hline
\end{tabular}




\begin{tabular}{|c|c|c|c|c|}
\hline $\begin{array}{l}\text { Ella, él y sus } \\
\text { millones }\end{array}$ & 1944 & Juan de Orduña & Comedia & Juan Quintero Muñoz \\
\hline Escándalo, El & 1943 & $\begin{array}{l}\text { José Luis Sáenz } \\
\text { de Heredia }\end{array}$ & Drama & $\begin{array}{l}\text { Manuel Parada de la } \\
\text { Puente }\end{array}$ \\
\hline Fin de curso & 1943 & Ignacio F. Iquino & Comedia & $\begin{array}{l}\text { Ramón Ferrés i } \\
\text { Mussolas }\end{array}$ \\
\hline $\begin{array}{l}\text { Florista de la reina, } \\
\text { La }\end{array}$ & 1940 & $\begin{array}{l}\text { Eusebio } \\
\text { Fernández } \\
\text { Ardavín }\end{array}$ & Drama & Juan Quintero Muñoz \\
\hline Héroes del 95 & 1947 & Raúl Alfonso & Bélico & Joan Duran i Alemany \\
\hline Hijo de la noche, El & 1949 & Ricardo Gascón & Drama & Joan Duran i Alemany \\
\hline Inés de Castro & 1944 & J. Leitao de Barros & Histórico & José Muñoz Molleda \\
\hline Locura de amor & 1948 & Juan de Orduña & Histórico & Juan Quintero Muñoz \\
\hline $\begin{array}{l}\text { María Fernanda "la } \\
\text { Jerezana" }\end{array}$ & 1946 & Enrique Herreros & Policíaco & Jesús García Leoz \\
\hline $\begin{array}{l}\text { Misterioso viajero } \\
\text { del Clipper, El }\end{array}$ & 1946 & $\begin{array}{l}\text { Gonzalo P. } \\
\text { Delgrás }\end{array}$ & Comedia & Joan Duran i Alemany \\
\hline Noche fantástica & 1943 & Luis Marquina & Drama & José Ruiz de Azagra \\
\hline Oro y marfil & 1947 & $\begin{array}{l}\text { Gonzalo P. } \\
\text { Delgrás }\end{array}$ & Comedia & $\begin{array}{l}\text { Manuel López- } \\
\text { Quiroga }\end{array}$ \\
\hline Pepe Conde & 1941 & José López Rubio & Comedia & $\begin{array}{l}\text { Manuel López- } \\
\text { Quiroga }\end{array}$ \\
\hline Raza & 1941 & $\begin{array}{l}\text { José Luis Sáenz } \\
\text { de Heredia }\end{array}$ & Bélico & $\begin{array}{l}\text { Manuel Parada de la } \\
\text { Puente }\end{array}$ \\
\hline $\begin{array}{l}\text { Tambor del Bruch, } \\
\text { El }\end{array}$ & 1948 & Ignacio F. Iquino & Bélico & $\begin{array}{l}\text { Ramón Ferrés i } \\
\text { Mussolas }\end{array}$ \\
\hline $\begin{array}{l}\text { Torre de los siete } \\
\text { jorobados, La }\end{array}$ & 1944 & Edgar Neville & Fantástico & José Ruiz de Azagra \\
\hline Turbante blanco & 1944 & Ignacio F. Iquino & Comedia & $\begin{array}{l}\text { Ramón Ferrés i } \\
\text { Mussolas, Joan Duran } \\
\text { i Alemany }\end{array}$ \\
\hline $\begin{array}{l}\text { Últimos de } \\
\text { Filipinas, Los }\end{array}$ & 1945 & Antonio Román & Bélico & $\begin{array}{l}\text { Manuel Parada de la } \\
\text { Puente }\end{array}$ \\
\hline
\end{tabular}

Tabla 1. Largometrajes visionados.

Elaboración de Esther García Soriano.

-Visionado de los filmes y consulta de partituras

Para acceder a los largometrajes enunciados se utilizaron tanto los recursos que alberga la Filmoteca Española, como videograbaciones personales. Durante los visionados se atendió tanto a la relación música-imagen (función o finalidad del fragmento sonoro en su secuencia correspondiente), como a la naturaleza misma de la obra musical en sí, considerando sus elementos (melodía, ritmo, armonía, dinámica, tempo, timbre, textura y forma) desde un punto de vista musicológico. Seguidamente, se consultaron las 
partituras correspondientes y diversos documentos adjuntos tales como contratos laborales, plantillas orquestales, guiones musicales y letras de canciones, que permitieron completar el estudio. Es necesario subrayar el difícil acceso a los mismos, muchos de los cuales han desaparecido o están en manos de familiares que no permiten su examen.

-Entrevistas

La posibilidad de entablar conversación con personajes relacionados directa $\mathrm{o}$ indirectamente con la música de cine español de la posguerra, constituye una importante herramienta, sobre todo cuando sus verdaderos protagonistas, es decir, los compositores de aquel período, así como sus obras o documentación diversa, resultan inaccesibles por distintas razones (fallecimiento, extravío de material, entre otros). La entrevista personal a D. Antoni Duran Barba, hijo del compositor Joan Duran i Alemany, sirvió para esclarecer dudas y vacíos de información que surgieron durante la investigación ${ }^{22}$. Durante la misma se realizaron preguntas relativas al trabajo del músico en el cine tales como su contratación, el proceso creativo, la grabación y resto de fases que tienen lugar en la elaboración de una banda sonora cinematográfica, que serán comentadas en próximos epígrafes.

\subsection{Características generales de la música en el cine español de la década de 1940}

Frente a las adaptaciones de zarzuelas y los simples esbozos de música original que componían las partituras cinematográficas de los años treinta en España, el período de posguerra va a destacar por la espectacularidad y grandilocuencia en la creación musical, con bandas sonoras extensas, sinfónicas y de un gran valor funcional. Características, por otra parte, similares a las de la música cinematográfica de Hollywood, cuyo lenguaje bebió de las sinfonías y conciertos de Brahms, Rachmaninov y Mahler; de la sonoridad de los ballets de Chaikovski; de la fuerza y pasión de los poemas sinfónicos de Dvorák, Franck o Saint-Saëns, y de la ópera romántica, la obra de arte total o Gesamtkunstwerk de Wagner, en donde varios lenguajes artísticos se funden en uno solo, tal y como ocurría con el séptimo arte. Alvares lo explica así: “...la música cinematográfica de nuestro país durante los años cuarenta sorprende por su calidad y espectacularidad. Siguiendo las directrices de la industria norteamericana, que 
comprendió que el lugar de la música en la banda sonora era fundamental para una buena película" (Alvares \& Arce, 1996: 186).

David Roldán Garrote afirma igualmente que los lenguajes musicales utilizados estuvieron "muy influenciados especialmente por los compositores hollywoodienses" (Roldán, 2005: 470). Pachón se refiere a ello como "asimilación inconsciente de corrientes extrajeras, sin intentar unos niveles de síntesis y adaptación mínimos" (Pachón, 1992: 95). Y Padrol afirma lo siguiente:

...no es original ni rompe moldes, no abre nuevos caminos ni cierra otros, no inaugura una etapa nueva en la evolución de la banda sonora mundial ni establece parámetros nuevos como punto de partida o modelo a partir del cual la banda sonora adquirirá un nuevo rumbo. Su genialidad reside simplemente en su inusitada perfección, que lleva a la culminación los postulados propuestos por Max Steiner y Erich Wolfgang Korngold desde su feudo de la Warner. (Padrol, 1986: 22).

Se podría decir entonces que los compositores españoles procedieron incorporando al cine la tendencia musical forjada en Hollywood en los años treinta, creada en los departamentos musicales de los estudios norteamericanos tras la llegada del sonoro, denominada "sinfonismo clásico cinematográfico" (Colón, 1997: 107), caracterizado por emplear un lenguaje adscrito al romanticismo y posromanticismo con algunos recursos impresionistas, de gran brillantez sinfónica y exageración sentimental.

Además de este deslumbrante estilo, las partituras cinematográficas del cine español de aquellos años integran el elemento popular. Alejandro Pachón emplea el término "neocasticismo" para calificar a los compositores españoles del cine de posguerra, cuya alusión más clara es el "estilo zarzuelero dieciochesco" (Pachón, 1992: 93). Con estas referencias cabría esperar que las partituras cinematográficas de estos hombres rezumaran música popular por todas sus páginas, tal y como se observaba en la zarzuela, repleta de ritmos y melodías folclóricas. Sin embargo, aunque esta música podía ser protagonista en algunas proyecciones, lo cierto es que su presencia en el cine de esta época era solo moderada respecto a años anteriores: "era un elemento anecdótico que sí gustaba a las clases más bajas de la sociedad y a los sectores rurales, pero que no llegó a más" (Roldán, 2005: 470). 
Pero el folclore no constituye por sí solo el ingrediente popular de aquellas obras. Este incluye también el jazz y los ritmos latinos, tan en boga en aquel momento. Estos encontraron en el cine un medio de difusión decisivo que se intensificó de la mano del disco y la radio, asegurando así la popularidad y venta de numerosos temas de la época. Más de un espectador acudía a las salas cinematográficas atraído por la canción de moda (Roldán, 2005: 469).

Para la consecución de una perfecta filiación entre los elementos descritos y la imagen, la composición original cinematográfica de este período se apoyaba en los clichés, que podrían definirse como fórmulas musicales que se repiten asociadas a una determinada imagen, compuestas en función de unos códigos que permiten prever el efecto que causarán en el oyente. Cuando la música emprendió su carrera como elemento expresivo del filme, comenzó a hacer uso de los estereotipos musicales. Una buena relación de la música con las diferentes escenas proyectadas equivalía a una buena imitación sonora de cada suceso visual. Para tal fin, se seleccionaba meticulosamente el repertorio, apto para todo tipo de eventos dramáticos, que los principales editores no tardaron en publicar. Determinadas obras se grabaron en la memoria de los espectadores ligadas a un acontecimiento cinematográfico específico. La cabalgata de las Valkirias de Wagner y la obertura de Guillermo Tell de Rossini ilustraban las persecuciones y galopadas, la Marcha nupcial de El sueño de una noche de verano de Mendelssohn las bodas, y la Marcha fúnebre de la Sonata $n^{\circ} 2$ Op. 35 de Chopin las situaciones de duelo o pérdidas. El mensaje llegaba a todos y de manera unívoca.

Por tanto, en beneficio de esta lograda comunicación, ante la ingente productividad fílmica durante la posguerra y el escaso tiempo otorgado a los músicos de cine para componer, cuando la composición original sustituyó a la música etiquetada, se vio en cierto modo obligada a asumir todas las fórmulas y convencionalismos que tan buenos resultados habían dado, satisfaciendo a la industria y deslumbrando al consumidor de manera rápida y efectiva desde hacía años.

La diversidad estilística conformaba así las partituras cinematográficas españolas de aquellos días, encabezada por el llamado sinfonismo, seguido de los aires folclóricos y la música popular urbana, que sustentaban las imágenes sobre la base de un conjunto de estereotipos musicales que garantizaban la plena comprensión del conjunto audiovisual. 


\subsection{Elaboración de la música cinematográfica en España durante la posguerra}

Una de las cuestiones abordadas en los estudios sobre música cinematográfica es la realización de una banda sonora con todas las fases que ello conlleva, desde la elección del compositor hasta la grabación musical, pasando por la etapa puramente creativa en la que se determinan los temas a emplear en el filme y sus características. Con el fin de que se observen con claridad las diferencias entre este proceso tal y como se relata en diversos de los volúmenes consultados y el modo en que tenía lugar en la década de los años cuarenta, y más concretamente en España, se realiza a continuación una panorámica de las diversas etapas que entraña la composición musical fílmica.

La primera de ellas es la lectura del guion cinematográfico a través del cual el compositor comienza a familiarizarse con la película, esto es, su género, los personajes, la época, etc. Leído el guion se entrevista con el director fílmico previamente al rodaje para conocer sus objetivos respecto a la música, lo que espera que ella aporte al filme, su finalidad esencial.

El siguiente paso es el visionado de un premontaje del material que, aunque puede ayudar al compositor, no le proporciona la información fidedigna que le otorga el visionado del montaje definitivo, mediante el cual determina elementos tales como el ritmo del largometraje, su estructura, interpretación de los actores, etc.

Tras este primer visionado es necesario realizar otros subsiguientes con el fin de seleccionar las partes que llevarán música, según la función que se persiga en cada caso. En esta fase, conocida como spotting session, intervienen el compositor, director, productor, editor filmico y editor musical, que establecen exactamente dónde ha de comenzar y terminar cada intervención musical, esto es, la duración de los distintos bloques musicales.

Seleccionados los momentos fílmicos que habrán de llevar música y su duración exacta, se deciden las características de dicho acompañamiento sonoro. En este punto, el director, conocedor en la mayoría de los casos del estilo y trabajos previos de un determinado compositor, lo selecciona como candidato ideal para cumplir con sus expectativas.

El proceso de creación musical implica nuevos visionados, conversaciones con el director $\mathrm{y}$ productor, muestras fraccionadas del trabajo, pruebas, cambios $\mathrm{y}$ correcciones. 
Una vez terminada la partitura es momento de instrumentarla. Para acelerar el trabajo y ante el escaso tiempo del que se dispone para sacar adelante la música de la película, a lo sumo tres semanas, esta tarea puede ser realizada por un orquestador, a cuyo término tiene lugar la extracción de las partichelas.

Una de las fases más laboriosas es la grabación, durante la cual ha de cuidarse minuciosamente la sincronización. Existen diferentes técnicas para conseguir un perfecto ajuste de la música con las diferentes imágenes previamente seleccionadas ${ }^{23}$. El director de orquesta, en caso de que no sea el propio compositor, es quien se pone al frente de la grabación tras los ensayos pertinentes con los instrumentistas. A estas sesiones también acuden el director y productor, quienes pueden solicitar al compositor que realice ciertos cambios en la música ante los resultados que se observan y perciben al escucharla junto a la imagen.

La última etapa es el denominado dubbing. Se trata de la mezcla de la música con los diálogos, efectos sonoros y canciones. La partitura puede quedar reducida a un mero fondo en muchos momentos del filme, según los requerimientos del mismo, para dar cabida a todos estos elementos. Por lo general, el compositor no asiste a estas sesiones, bien porque se encuentra al frente de un nuevo proyecto y en parte porque pueden resultar un poco desmoralizantes, ya que le permiten comprobar en lo que ha quedado reducido su trabajo tras la mezcla sonora.

A través de estudios como los elaborados por Karlin (1994), Prendergast (1992), Nieto (1996) y otros ${ }^{24}$, de los que se ha extraído la información expuesta en este epígrafe, se conocen con exactitud las diferentes fases enunciadas que componen esta laboriosa tarea, las técnicas que entrañan y los profesionales que intervienen en ellas, desde la época del cine mudo hasta la actualidad, con Hollywood como principal referente. No obstante, cuando se trata de la elaboración de una banda sonora cinematográfica en la década de los años cuarenta en España, las fuentes a consultar son muy diferentes.

De vital importancia son las declaraciones hechas por los propios músicos a la prensa de la época con motivo de un estreno cinematográfico o la obtención de algún premio, y las entrevistas realizadas hoy en día a sus familiares y a distintos especialistas del cine y de la música. Todo ello permite cotejar los procedimientos norteamericanos con los empleados en España en aquel momento. Asimismo, cabe destacar la documentación musical fílmica del período, como partituras y guiones musicales que aún se conserva 
en manos de particulares, archivos y bibliotecas, con anotaciones primordiales sobre el tema. Tras la consulta de la bibliografía y demás materiales, se expone la información obtenida.

En la época investigada, la música del cine hollywoodiense estaba en manos de los departamentos musicales, desarrollados por los propios estudios cinematográficos. El director del departamento, en gran medida guiado por sus preferencias personales, era el encargado de seleccionar al compositor. Una vez empleado, este se convertía en un especialista más en la cadena de producción musical cuya vinculación con la empresa podía ser permanente a través de un contrato a largo plazo, que le obligaba a colaborar en tantas películas como se filmaran.

A diferencia de Estados Unidos, España carecía de unos estudios equiparables a los norteamericanos con secciones musicales propias. Los compositores españoles no firmaban convenios fijos. Trabajaban de manera independiente y eran escogidos directamente por el director o productor de la película para colaborar en un proyecto específico: "En lo que a música de cine se refiere, el hecho diferencial europeo -como en la década anterior, pero aún con más fuerza- será la ligazón creativa entre los compositores y los realizadores. Los músicos no se vinculan con casas de producción o con géneros, como en Estados Unidos, sino con proyectos personales y -a través de ellos-con movimientos ético-estéticos" (Colón, 1993: 71).

En las cláusulas de estos acuerdos quedaban establecidos, entre otros puntos, la concesión al productor del derecho de reproducción de la banda musical y el tiempo máximo de su explotación fílmica, los honorarios del compositor y su derecho de ejecución y reproducción de la obra por vías ajenas a la cinematográfica. Todo ello se puede observar en el siguiente documento fechado en Barcelona el 16 de Diciembre de 1948 que vincula a Joan Duran i Alemany con Antonio Bofarull, productor de la película Ha entrado un ladrón (1949) de Ricardo Gascón (véase figura 1). 


\section{C.0.1.X.1.2.}

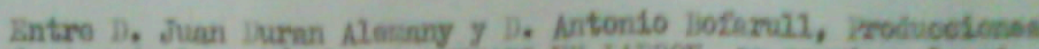

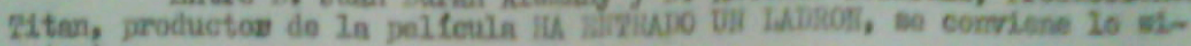
guiente:

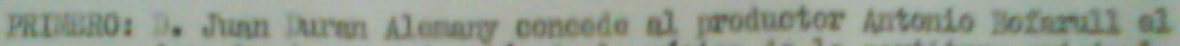

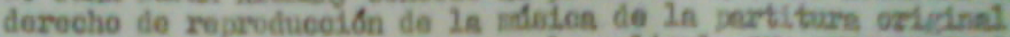

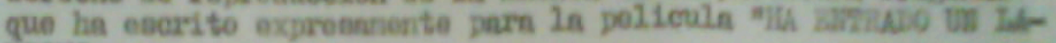
ineor".

ssoum0a fura in concesion exeluaiva de ente derecio de reproduceion eine-

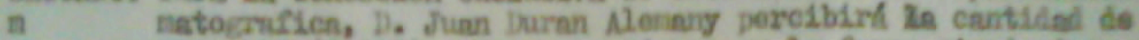

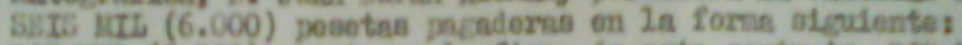
DOS IIf $(2.000)$ peoetas a la firna de este contrato, DOS imb (2.000) penetas a los veinte dins de cononeado el rodnje y Dos luth $(2.000)$ pesotas al ternitrex in musica de fondo $y$ despues de an madicion. Fintendiendo quo nediante el cobro de la eitada cantilad.Juen Durna Alenany, solo trensilope el derecho de reproduccion cinentocrifica nencionndo pem in citala poliesIn, roservandose el derecho de ejecueion y reproduccion da discos planolas, edición papel etc.. y en ceneral en cualquior otro nodie distinto del cinoantografo.

FKRCiRa: Aunque el productor D. Antonio Bofarull podr' exploter la pelickIs a que este contrato ae rofiere todo el tienpo que eative opor tuno, el derocho que le concede el $\mathrm{r}$. Iurna Alenny Pinalizard a 10 a aiete allos a contar de la fecha de in firna de eote controto, pudiondo entonces el gutor disponer de cus nuveros mueicales para aplicarlos incluso \& otm policula distinta.

CUnis0: II autor se conjaronete a no fijar derechos ni tarifía eepeciales para la presentacion y projecolón publica y que hinbrin que pasyr. Is enpreans donde se proyecte ls peliculn. BI autor so linitars a exifir las tarías corrientos fijadas a loe locales y enpreans por la Sociedad General de Autoren sepaitoles.

$I$ pers que conste a 100 efectos pertinentes, 10 fiman por tripliesdo on farcelona s diea $\mathrm{y}$ sole de Dicienture de mil novecientos cusrenta $\mathrm{g}$ ocho.

Figura $1^{25}$. Contrato entre Joan Duran i Alemany y Antonio Bofarull, productor de la película $H a$ entrado un ladrón (1949), de Ricardo Gascón. Barcelona: Archivo personal de Antoni Duran Barba.

La decantación por uno $\mathrm{u}$ otro compositor tenía que ver con sus trabajos previos conocidos, en donde quedaban de manifiesto el estilo o estilos en los que mejor se desenvolvía el músico. Luego, si este entablaba una buena relación con el director o la casa productora, es posible que se asociaran en más proyectos. No obstante, el orden podía ser a la inversa. La amistad previa aseguraba el empleo de antemano. Francisca Martos comentaba al respecto sobre lo acontecido a su esposo Juan Quintero:

Durante la guerra mi marido (que todavía era soltero) trabajaba en el Infanta Isabel donde había un teatro. Allí trabajaba con él Guadalupe Muñoz Sampedro, que debido a los bombardeos se fue a vivir cerca de donde vivía mi marido. Durante este período oía mucho tocar el piano a Juan y ella se lo comentó a Juan de Orduña diciéndole: "en mi escalera vive un músico, un pianista, excelente que toca muy bien el piano". Orduña, que era un gran aficionado a la música clásica quiso que le presentasen a mi marido para que le tocase 
piezas al piano. Y un buen día Guadalupe lo hizo. Por aquel entonces Orduña era solo actor. Y a partir de entonces tuvimos una amistad enorme (Roldán, 2004: 385).

Las relaciones sociales entre los profesionales del medio eran determinantes para llegar a formar parte de un proyecto: "Mi padre -refería Antoni Duran- se reunía casi cada día en la Plaza de Cataluña, en el Salón Rigart, donde iban los directores, los músicos, etc. Allí hablaban, hacían sus componendas y surgían los trabajos"26.

Una vez elegido el compositor, era necesario informarle sobre la película y sus características, esto es, el argumento, la época, el género y los personajes. Para ello estaba el guion cinematográfico a través del cual se familiarizaba con el filme y reflexionaba sobre la finalidad que tendría la música dentro del mismo. Antoni Duran recordaba lo siguiente al respecto sobre la labor de su padre, Duran i Alemany: "Normalmente le daban un guion, y él sobre el guion hacía la música, pues calculaba los tiempos de cada escena, etc., etc., y el tema que fuera acorde con de lo que se trataba" ${ }^{27}$. Leído el guion, el director se reunía con el compositor para comunicarle sus ideas sobre la banda sonora que deseaba en cuanto a lenguaje o estilo, y lo que esta aportaría a la película. El creador podía exponer su punto de vista al respecto: "El músico, como todos los colaboradores, los intérpretes especialmente, puede proponer al director cuanto le parezca oportuno dentro de su colaboración. Si el director acepta la sugerencia, sin duda era buena y mejora la obra” (Roldán, 2004: 385).

Del mismo modo, cuando la película requería música diegética sincronizada, el director se lo hacía saber al compositor inmediatamente ya que se necesitaba para poder filmar la escena o escenas en donde dichas piezas intervenían. Con tal fin, el músico la creaba en primer lugar, antes que la partitura incidental. También podía emplear obras preexistentes, en cuyo caso efectuaba una adaptación de las mismas. Grabadas las canciones o bailables exigidos, se reproducían en playback durante el rodaje. A veces, los propios músicos tomaban partido en la grabación de estos números. Tal es el caso de Joan Duran i Alemany quien, sentado al piano, acompañaba su canción $P u-p u-p i-d u$ en el filme El difunto es un vivo (1941), de Ignacio F. Iquino (véase figura 2). 


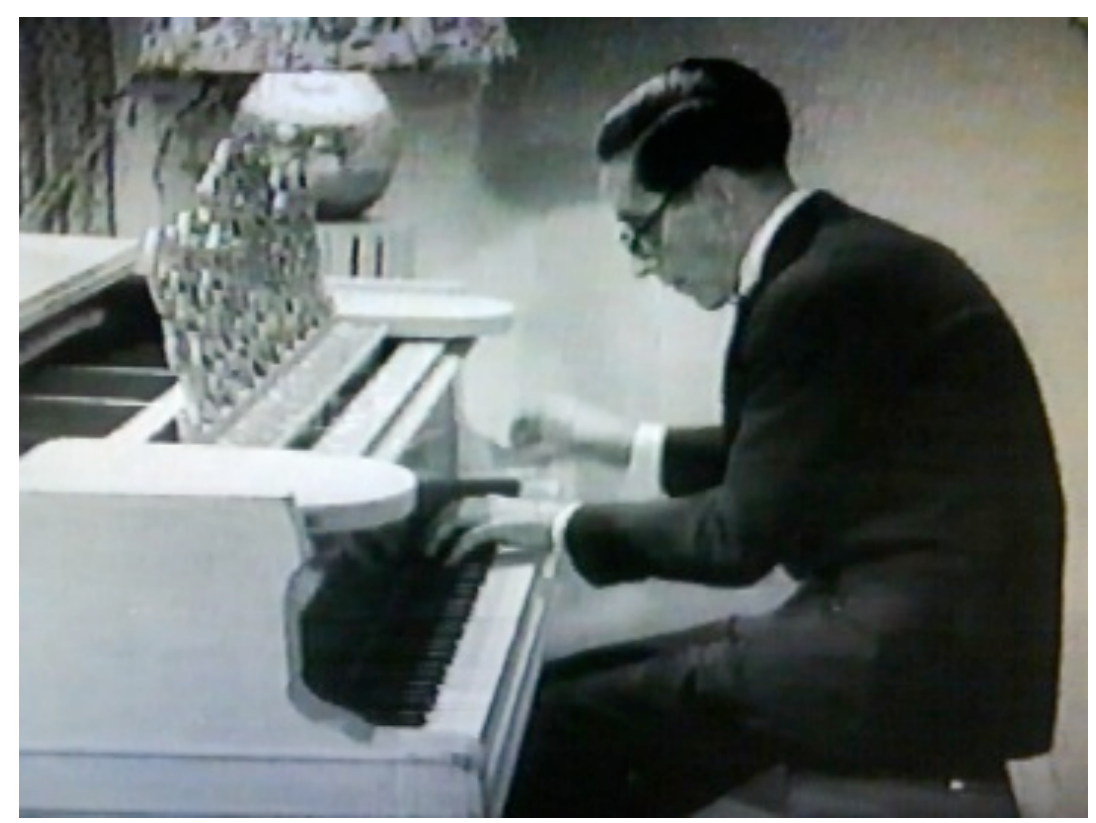

Figura 2. Joan Duran i Alemany en el filme de Ignacio F. Iquino, El difunto es un vivo (1941). Barcelona: Archivo personal de Antoni Duran Barba.

Llegados a este punto, era hora de filmar. El autor de la partitura asistía a los rodajes de manera habitual. De esta forma iba recibiendo información visual acerca de las ideas teóricas adquiridas a través del guion sobre el argumento, la época y los personajes, lo que le permitía establecer con mayor exactitud el estilo y carácter de su obra. Así es como procedía García Leoz según el director de cine José Antonio Nieves Conde: "Venía a los rodajes, veía lo que se iba rodando. Y durante todo este tiempo iba trabajando" (Roldán, 2004: 396).

Sin embargo, la banda sonora no estaba completamente definida hasta que la película podía verse proyectada en una pantalla. Solo entonces se advertía la importancia de algunas secuencias o planos y la trivialidad de otros, su duración y cómo enlazaban entre sí, determinando el ritmo fílmico. Sin el conocimiento de estos aspectos, las funciones expresivas y estructurales de la música en el filme no podían quedar plenamente constituidas. El testimonio de García Leoz evidencia este proceso con la riqueza de aquel que fue uno de los protagonistas de esta etapa: 
A veces, la realización varía del guion proyectado; han desaparecido escenas y han nacido otras, y lo más frecuente es la sorpresa de que determinados $<<$ planos $>>$ que leyendo el guion no tenían demasiado relieve, antes bien eran grises, luego, al realizarse, ganaron en belleza, alcanzaron una plasticidad que está pidiendo a voces música, mucha música y la mejor posible, y en cambio, se encuentra uno también sorprendido porque la escena que leída en el guion parecía relevante, luego, ya en imágenes, pierde el supuesto relieve (Anónimo, 1946b).

Por todo ello, al concluir el rodaje, se invitaba al compositor a un primer visionado de una copia de trabajo o premontaje del filme ${ }^{28}$. Sobre ella se seleccionaban las escenas que llevarían música y los momentos exactos donde esta comenzaría y terminaría, según los efectos que se pretendieran conseguir con ella sobre las imágenes, tales como el subrayado de las palabras, la descripción de ambientes, la caracterización del tiempo, la identificación de personajes, la unión o separación de escenas, la anticipación de imágenes, entre otros, acordados con el director. Todo se anotaba con precisión: se describía brevemente la acción y la imagen de las escenas elegidas, algunas características del acompañamiento musical correspondiente (matices, tempo, timbre y otros) así como su duración, y se numeraban los bloques resultantes dando lugar al guion musical. Volvemos al testimonio de García Leoz: "Se proyecta rollo por rollo, y al término de la proyección se proponen los fondos y subrayados musicales. Los directores discuten, en general, poco. Se llega en seguida a un acuerdo. Entonces, el mismo rollo se pasa por la moviola para medir con precisión matemática la duración de cada escena o fracción de escena" (Anónimo, 1946b).

Discutidos todos los puntos y fijados los bloques musicales, se iniciaba la ardua tarea de la composición. La principal fuente de inspiración de los músicos españoles eran los compositores norteamericanos de la época, cuyas bandas sonoras escuchaban cuando acudían al cine, afición generalizada entre los profesionales del sector. Antoni Duran comenta sobre su padre: "Con mi madre iba mucho al cine. Entonces echaban dos películas y además hacían espectáculo a veces, había alguna vocalista, una así que cantaba. Iba mucho al cine, le gustaba mucho, y los músicos como Gershwin, Rózsa"29. A diferencia del vestuario o la escenografía, que estaban preparados y listos antes de comenzar el rodaje, la música no podía ni debía escribirse antes de que el montaje hubiera concluido, como afirmaba Parada (Anónimo, 1946a), esto es, una vez finalizada la película. Entonces, a la espera únicamente de incorporar la banda sonora para poder 
estrenar el largometraje, los directores y productores apremiaban a los músicos a los que les concedían apenas dos semanas para realizar la partitura. García Leoz lo expresaba de esta manera: "Creo que se ha llegado a una completa compenetración entre músico y director, que facilita enormemente el trabajo. El único inconveniente que encuentro es el agobio, la falta de tiempo, ya que la partitura no se puede hacer hasta que no esté terminada la película, y entonces hay prisa por estrenar" (Anónimo, 1946a).

Quintero se manifestaba de la misma forma: "El defecto mayor es la prisa con que hay que hacer las partituras. Cuando llega al compositor el "copión" para poder trabajar, siempre hay compromisos de estreno tan próximos que tenemos que trabajar a marchas forzada" (Anónimo, 1946a). Prácticamente todos los creadores expresaron alguna vez su disconformidad con esta exigencia que impedía o, al menos, dificultaba la consecución de un resultado satisfactorio. Así lo exponía Duran i Alemany: "Haríamos en España mejor cine si no se improvisara tanto. Eso de que le digan a uno: el miércoles, la música de fondo, y el lunes están pasando el guion para ajustar la música a las escenas, no puede ser. No dejan tiempo material para buscar detalles" (A, 1943). Ruiz de Azagra alegaba argumentos similares: "En España hay autores que pueden hacer las cosas tan bien como pueden hacerlo los ingleses o los americanos. Ahora bien, lo que hace falta es que nos encarguen las cosas con tiempo y no nos obliguen a hacer la música de una película en cuatro días" (Anónimo, 1946a).

A lo largo de esta intensa tarea, se elaboraba primero un borrador para piano de toda la partitura, con las anotaciones pertinentes acerca de los bloques (número y/o título, duración y notas de sincronización) y después se procedía a la orquestación. Mientras que en Hollywood, existían especialistas designados para realizar con normalidad esta actividad, en España, el compositor era al mismo tiempo el orquestador. La falta de medios y la baja consideración que se tenía de la música en la industria cinematográfica nacional en esta época, obligaba a los compositores a desempeñar todo tipo de funciones más allá de la puramente creativa tales como la orquestación, la contratación de los músicos, la dirección orquestal durante los ensayos y la grabación (Arce, 1999: 5). Sin embargo, esto no excluía la participación de entendidos en épocas de intenso trabajo, como prueban estas líneas de García Leoz dirigidas a su orquestador: “Amigo Adolfo $^{30}$ : este es el último numerito que te ruego me instrumentes, pero quisiera entregarlo en copistería mañana antes de las doce. Como verás es muy claro y lo quiero 
con gran predominio de la cuerda, casi sin metal, como una danza dieciochesca a lo Gluck. (El número de la caza del mono está muy bien entendido y sonará muy bien)”31. Donde sí intervenían regularmente los colaboradores era en la elaboración de las partichelas. En los márgenes de las propias partituras orquestales se pueden leer notas escritas por los compositores dirigidas a sus copistas, como estas de García Leoz: "Copia claro, y pon matices, cambios de tiempo, etc., que lo pago yo"32.

Extraídas las partes para los distintos instrumentos, era momento de reunir a los músicos, ensayar y prepararse para la grabación. Frente a los estudios norteamericanos que poseían sus propias orquestas de unos cuarenta y cinco o cincuenta ejecutantes, las productoras españolas, ante la carencia de tales servicios, suministraban una determinada cantidad de dinero al compositor y le encargaban la contratación de los intérpretes. Algunos maestros como Duran i Alemany contaban con ayudantes para llevar a cabo esta labor: "Normalmente tenía un asesor al que le decía: necesito cuatro trompetas, dos trombones, cinco violinistas, un fagote, un oboe, lo que fuera según la partitura que tenía, y le buscaba los contactos. Sí que buscaba personalmente, cuando podía, buenos solistas" 33 .

Realizados los pertinentes ensayos, llegaba el momento de la grabación. Los compositores eran los responsables de dirigir la orquesta al tiempo que sincronizaban la música con la imagen, como atestiguan estas líneas de García Leoz dirigidas a su copista: "Aunque falta el trío del Pasodoble, me basta con esto para la película. Házmelo lo antes posible, pues la semana que viene registro música y quisiera hacer la banda a la vez. Leoz" ${ }^{34}$.

En Estados Unidos, para lograr una perfecta sincronización de la música con la imagen se aplicaban distintas técnicas como el metrónomo (click track), las serpentinas y perforaciones (free timing) y otras ${ }^{35}$, mediante las cuales, a través de sonidos durante la grabación o marcas sobre los fotogramas, el director sabía con exactitud dónde debía empezar y acabar la música, y el tempo exacto al que debía interpretarse mientras dirigía. En España, el único recurso con el que contaba el compositor para dirigir la orquesta en conexión con la película era su proyección en una pantalla, sin ningún tipo de marca sonora o visual. Incluso no siempre se contaba con el visionado del filme en estas sesiones. Quintero disponía de un cronógrafo, las notas de sincronización escritas en la partitura y la ayuda de su esposa que le indicaba gestualmente si debía acelerar o 
frenar en algún pasaje (López, 2009: 337). Eran áridas jornadas de trabajo en las que hasta el carácter más apacible, como el de Duran i Alemany, se veía alterado al final del día: "Mi padre -relataba Antoni Duran- más bien era pacífico y allí cambiaba completamente, se ponía muy enérgico. Decía: “¡Tú has desafinado!, ¡Tú has entrado tarde!". Empezaba muy pronto y terminaba muy tarde cada día, era un trabajo duro. Recuerdo que llegaba a casa cansado y además se movía mucho dirigiendo"36.

Junto a la complicada sincronización música-imagen, estaban los cambios musicales de última hora. Durante la grabación es posible que el compositor se viera obligado a modificar algún fragmento musical por exigencias del director o productor. FernándezCid apunta al respecto sobre Jesús García Leoz: “...en los registros, cuando, sin tiempo casi, habían de cortarse compases, rectificar, añadir, surgía el artista de cuerpo entero, para quien todos los problemas de su especialidad estaban superados" (Fernández-Cid, 1953: 18). Más adelante añade:

Una vez, el corte aceptado con dolor, con rabia, porque mutilaba calidades musicales que se lograran con amoroso celo. Otra, u otras, una feliz solución para la demanda insólita expuesta con la mayor naturalidad: <<Aquí necesito unas campanitas; falta medio minuto de fondo sonoro; en vez de violines, Jesús, ¿por qué no utilizas trompas?: resultan más adecuadas a los matices psicológicos $>>$. Y Leoz quitaba, ponía, cooperaba con un talento envidiable; negaba, solo en los casos extremos, luego de convencer a todos de su razón (25).

A estas duras sesiones de actividad se sumaban las precarias salas en donde se realizaban. La ausencia de lugares habilitados para tales prácticas obligaba a efectuarlas en cualquier parte (Roldán, 2004: 192). Hasta los estudios algo más equipados evidenciaban penurias y desperfectos. Duran i Alemany lo relata con crudeza: “...faltan Estudios de sonorización. Los que existen no están hechos con arreglo a las leyes acústicas, y el que no tiene mala resonancia, tiene una sequedad que ahoga... y hasta algunos con el piano desafinado" (A, 1943).

Grabada la música, no quedaba sino mezclarla con los demás elementos sonoros del filme adjudicándole el plano más adecuado en cada caso. Sin duda esta era la fase más frustrante de todas para el compositor quien veía cómo el producto de su trabajo en muchas ocasiones se malograba. Los técnicos, ignorantes de toda cuestión musical, manipulaban la banda sonora con total libertad teniendo en cuenta solo la percepción 
del diálogo, lo que arruinaba la dinámica en cualquier punto de la partitura: "El músico podía llegar a perder mucho si no estaba allí y 'luchaba' de algún modo por el respeto a su obra" (Roldán, 2004: 193). A esto había que añadir la baja calidad de los medios utilizados, todo lo cual originaba un audio altamente deslucido. No sería hasta tiempo después, con la evolución y mejora de las tomas de sonido, de los micrófonos y de los sistemas de captación sonora, cuando la categoría de la obra musical dejaría de estar camuflada y de resultar inapreciable dentro del conjunto fílmico.

\section{Conclusiones principales del estudio}

-El acercamiento progresivo de la musicología al estudio de la música cinematográfica española de posguerra ha enriquecido este campo, el cual venía siendo abordado durante años por especialistas sobre el séptimo arte pero no así sobre música, lo que se traducía en aproximaciones livianas a la materia enfocadas básicamente en el aspecto biofilmográfico de los compositores de aquel período. En la actualidad, son cada vez más numerosos los análisis exhaustivos, en cuanto a la relación música-imagen, permitiendo complementar y enriquecer los estudios pretéritos. No obstante, es un terreno difícil en el que adentrarse debido a la escasez de fuentes, así como el difícil acceso a las mismas. Las películas, donde cohabitan música e imagen, constituyen el instrumento básico, y muchas veces único, para su examen.

-Pese a las limitaciones impuestas a la cinematografía nacional durante la década de 1940, gracias a una serie de directores como José Luis Sáenz de Heredia, Edgar Neville, Rafael Gil, Juan de Orduña, Ignacio F. Iquino, entre otros, el cine nacional logró destacar en una amplia gama de géneros, con preponderancia del drama y la comedia.

-La mayoría de las bandas sonoras compuestas para dichas producciones fueron creadas por un reducido grupo de músicos formado por Jesús García Leoz, Juan Quintero Muñoz, Manuel Parada de la Puente, Joan Duran i Alemany, José Ruiz de Azagra, José Muñoz Molleda, Ramón Ferrés i Mussolas y Manuel López-Quiroga que, como seguidores y amantes del cine hollywoodiense, supieron plasmar en ellas el nivel y calidad de la música fílmica norteamericana.

-Con dichos maestros se asentó la profesión de compositor cinematográfico en España, con unas pautas concretas a seguir en la elaboración de la banda musical, pero con 
importantes diferencias respecto a Hollywood, que contaba con departamentos musicales, especialistas a los que se les asignaban diferentes tareas, orquestas y convenios que ligaban a los músicos con una productora durante varios años. El resultado se hacía notar en la saturación de trabajo que debía asumir el compositor español, en muchos casos, exclusivo responsable de todas las fases que comprendían la creación de la música para un largometraje.

-La dedicación y talento demostrados en el medio por estos músicos, quedaron plasmados en partituras espectaculares, sinfónicas, de estilo decimonónico, aderezado con la presencia del elemento popular, folclórico y urbano, en función de los requerimientos de las imágenes, con las que establecieron una perfecta relación empática, a través del empleo de un elevado número de clichés musicales, lo que garantizaba la comprensibilidad de la audiencia, siguiendo las directrices de la música norteamericana, fuente primigenia de aprendizaje e inspiración para todos ellos.

\footnotetext{
${ }^{1}$ Para más información sobre los comienzos de la prensa musical especializada, consultar el apartado de McCarty, C. (1989). The Literature of Film Music, en McCarty, C. (Ed.). (1989). Film Music 1. Nueva York: Garland; ix-3.

${ }^{2}$ Sus trabajos correspondientes son:

Sabayenev, L. (1935). Music for the Films: A Handbook for Composers and Conductors. Londres: Pitman and Sons.

London, K. (1936). Film Music: A Summary of the Characteristics Features of its History, Aesthetics, Technique and Possible Developments. Londres: Faber and Faber.

${ }^{3}$ Concretamente con las siguientes:

Adorno, T. W. \& Eisler, H. (1947/2007). Composing for the Films. Londres: Continuum.

Huntley, J. (1947). British Film Music. Londres: British Year Books.

Levy, L. (1948). Music for the Movies. Londres: Sampson Low.

${ }^{4}$ Algunas de las investigaciones básicas en este campo son:

Chion, M. (1997). La música en el cine. Barcelona: Paidós.

Lack, R. (1999). La música en el cine. Madrid: Cátedra.

5 Jesús García Leoz (Olite [Navarra], 10-I-1904; Madrid, 25-I-1953). Inició su carrera cinematográfica en los años treinta, firmando la partitura del primer largometraje Sierra de Ronda en 1934 a las órdenes de Florián Rey. Su labor en este campo fue reconocida en tantas ocasiones por el Círculo de Escritores Cinematográficos que se llegó a pensar en entregarle un último premio y así dejar paso a otros creadores del momento.

6 Juan Quintero Muñoz (Ceuta, 29-VI-1903; Madrid, 26-I-1980). Su obra fílmica comenzó con las Sevillanas Imperio para el filme La hermana san Sulpicio (1934), de Florián Rey. Varios de sus trabajos le valieron importantes reconocimientos, como los del Círculo de Escritores Cinematográficos en 1946 por La pródiga y Un drama nuevo. Asimismo, por su partitura para Locura de amor (1948), de Juan de Orduña, fue galardonado con el premio a la mejor música en el Certamen Cinematográfico Hispanoamericano. Fue jefe de la sección cinematográfica de la SGAE.

7 Manuel Parada de la Puente (San Felices de los Gallegos [Salamanca], 26-VI-1911; Madrid, 10-VII1973). Fue galardonado en 1948 por el Círculo de Escritores Cinematográficos por La vida encadenada de Antonio Román, y en 1950 recibió el Premio Miguel de Cervantes a la mejor música por La noche del sábado. Asimismo, su productividad cinematográfica fue reconocida en 1963 con el Premio Nacional del Sindicato del Espectáculo.

${ }^{8}$ José Ruiz de Azagra (Madrid, 13-I-1900; Madrid, 17-VI-1971). Sus comienzos en el cine, de la mano de Florián Rey, datan de 1935, con el cortometraje Soy un señorito. Hasta 1956, momento en que abandona
} 
la industria, trabaja a las órdenes de Ignacio F. Iquino, Luis Marquina, Gonzalo P. Delgrás y Luis Lucia, principalmente. Fuera del medio destacó en la composición de canciones, revistas y zarzuela chica.

9 Joan Duran i Alemany (Barcelona, 21-IX-1894; Barcelona, 22-IV-1970). Tuvo su primer contacto con el cine en Alemania a finales de los años veinte cuando se dedicaba a tocar el piano y a dirigir su propia orquesta. Fue entonces cuando le contrataron como orquestador para las compañías UFA y Tobis. En su país ocupó el puesto de director artístico de la productora Parlophone. Compuso música para anuncios publicitarios. Como Parada, también escribió piezas para NO-DO. No dejó de componer hasta su muerte. ${ }^{10}$ Entrevista inédita realizada por Esther García Soriano a Antoni Duran Barba el 14 de julio de 2010.

${ }^{11}$ De hecho, solía realizar versiones de sus obras, y su Concierto breve para piano y orquesta está escrito en memoria del compositor americano.

12 Manuel López-Quiroga (Sevilla, 30-I-1899; Madrid 13-XII-1988). Cultivó la canción folclórica andaluza desde su juventud, época en la que sentado al piano amenizaba los intermedios de las funciones teatrales. De igual modo se inició en el campo de la zarzuela, la revista y todo tipo de obras líricas. Abandonó su ciudad natal en 1929 en dirección a Madrid donde continuó su labor compositiva, esta vez como escritor de cuplés. Enseguida conoció al letrista Rafael de León con quien comenzó a trabajar alcanzando su primer gran éxito con el pasacalle Rocio. Una vez que adquirió fama en la capital inició su carrera cinematográfica firmando la partitura del cortometraje Mi patio andaluz en 1933, de Zeisler y Loesen. Sin embargo no sería hasta después de la guerra civil cuando comenzó a destacar en la industria. A partir de los años cincuenta su labor cinematográfica fue disminuyendo hasta cesar del todo a mediados de los sesenta.

${ }^{13}$ Ramón Ferrés i Mussolas (Valls [Tarragona], 3-III-1878; Barcelona 7-III-1962). Entró en el ámbito cinematográfico tras una larga trayectoria unido al mundo lírico como compositor y fundador de una compañía de zarzuela que le llevó de gira por toda España y América junto a su esposa. Su primera participación en la industria tuvo lugar en 1933 con la película El relicario, de Ricardo de Baños. En 1935 firmó la partitura del largometraje, Al margen de la ley, de Ignacio F. Iquino. Tras dejar el cine regresó al teatro lírico.

${ }^{14}$ José Muñoz Molleda (La Línea de la Concepción [Cádiz], 16-II-1905; Madrid, 26-V-1988). Ingresó en el mundo del cine a finales de los años treinta, a través de la canción ligera, género que le había reportado importantes éxitos y del que siguió haciendo gala en la pantalla grande. Residió buena parte en el extranjero trabajando para los estudios de UFA y Cinecittà. Acumuló numerosos galardones y reconocimientos a lo largo de su carrera musical tales como el Premio Nacional de Música o el Premio Nacional de Barcelona, entre otros, y en 1962 fue nombrado académico de número de la Real Academia de Bellas Artes de San Fernando, momento a partir del cual menguó su actividad compositiva. Su trabajo y dedicación le condujeron a ocupar diversas funciones en la SGAE, entre ellas desempeñó el cargo de consejero delegado de la sección de cinematografía y televisión.

${ }^{15}$ Los congresos de Música y Cultura Audiovisual (MUCA), así como los organizados por la Sociedad Española de Musicología (SEdeM) son, entre otros, algunos de los más destacados, donde se da cabida a comunicaciones y ponencias sobre la creación musical cinematográfica nacional e internacional.

${ }^{16}$ Algunos estudios destacados son:

López, J. (2009). Música y cine en la España del franquismo: el compositor Juan Quintero Muñoz (19031980). Universidad de Granada. Tesis doctoral dirigida por Antonio Martín Moreno.

Miranda, L (2011). Manuel Parada y la música cinematográfica española durante el franquismo: estudio analítico. Universidad de Oviedo. Tesis doctoral dirigida por Celsa Alonso González.

Celaya, L. (2014). Vida y obra de Jesús García Leoz (1904-1953). Universidad Pública de Navarra. Tesis Doctoral dirigida por Isabel Ostolaza Elizondo y Marcos Andrés Vierge.

${ }^{17}$ Algunos títulos destacados son:

Xalabarder, C. (1997) Enciclopedia de las bandas sonoras. Barcelona: Ediciones B.

Padrol, J. (1998). Pentagramas de película: entrevistas a grandes compositores de bandas sonoras. Madrid: Nuer.

Cueto, R. (2003). El lenguaje invisible. Entrevistas con compositores del cine español. Madrid: 33 Festival del Cine de Alcalá de Henares, Comunidad de Madrid.

${ }^{18}$ Una de ellas es la coordinada por CALVO, F. (1986). Evolución de la Banda Sonora en España: Carmelo Bernaola. Alcalá de Henares: Festival de Cine de Alcalá de Henares.

${ }^{19}$ Algunas investigaciones de esta categoría son:

Romagueira i Ramió, J. (2002). El jazz y sus espejos. Madrid: Ediciones de la Torre.

Carmona, L. M. (2007). La música en el cine español. Madrid: Cacitel. 
${ }^{20}$ Destacan Primer Plano y Radiocinema.

${ }^{21}$ Entre las más interesantes y fidedignas cabe mencionar:

Base de datos de películas calificadas del Ministerio de Cultura (España). (www.mcu.es/cine/index.html) (10-10-17).

The Internet Movie Data Base (IMDB). (www.spanish.imdb.com) (10-10-17).

The Film Database. (www.citwf.com) (10-10-17).

${ }^{22}$ De entre todos los herederos con los que se pudo establecer contacto, tan solo D. Antoni Duran Barba concedió una entrevista personal.

${ }^{23}$ Los denominados clicks, serpentinas, perforaciones o el sistema Newman, entre otros, en Karlin, F. (1994). Listening to Movies. The Films Lover's Guide to Film Music. Nueva York: Schirmer Books, $45-$ 49.

${ }^{24}$ Otros referentes fundamentales para la elaboración de este punto han sido:

López, J. (2009). Música y cine en la España del franquismo: el compositor Juan Quintero Muñoz (19031980). Universidad de Granada. Tesis doctoral dirigida por Antonio Martín Moreno; 305-344.

Roldán, D. (2004). Fuentes documentales para el estudio de la música en el cine español de los años 40. Universidad Politécnica de Valencia. Tesis doctoral dirigida por Eulalia Adelantado Mateu; 185-198.

${ }^{25}$ Se transcribe de acuerdo con las normas ortográficas actuales:

CONTRATO / Entre D. Juan Durán Alemany y D. Antonio Bofarull, Producciones / Titán, productor de la película HA ENTRADO UN LADRÓN, se conviene lo siguiente: / PRIMERO: D. Juan Durán Alemany concede al productor Antonio Bofarull el / derecho de reproducción de la música de la partitura original / que ha escrito expresamente para la película "HA ENTRADO UN LADRÓN". / SEGUNDO: Para la concesión exclusiva de este derecho de reproducción cinematográfica, / D. Juan Durán Alemany percibirá la cantidad de / SEIS MIL (6000) pesetas pagaderas en la forma siguiente: / DOS MIL (2000) pesetas a la firma de este contrato, DOS MIL / (2000) pesetas a los veinte días de comenzado el rodaje y / DOS MIL (2000) pesetas al terminar la música de fondo y después / de su audición. Entendiendo que mediante el cobro de la citada / cantidad Juan Durán Alemany, solo transfiere el derecho / de reproducción cinematográfica mencionado para la citada película, / reservándose el derecho de ejecución y reproducción de discos / pianolas, edición papel etc. y en general en cualquier otro medio / distinto del cinematográfico. / TERCERO: Aunque el productor D. Antonio Bofarull podrá explotar la película / a que este contrato se refiere todo el tiempo que estime oportuno, / el derecho que le concede el Sr. Durán Alemany finalizará / a los siete años a contar de la fecha de la firma de este contrato, / pudiendo entonces el autor disponer de sus números musicales / para aplicarlos incluso a otra película distinta. / CUARTO: El autor se compromete a no fijar derechos ni tarifas especiales / para la presentación y proyección pública y que habrán de pagar / las empresas donde se proyecte la película. El autor se limitará / a exigir las tarifas corrientes fijadas a los locales y empresas / por la Sociedad General de Autores Españoles. / Y para que conste a los efectos pertinentes, lo firma por triplicado / en Barcelona a diez y seis de Diciembre de mil novecientos cuarenta / y ocho.

${ }^{26}$ Entrevista inédita realizada por Esther García Soriano a Antoni Duran Barba el 14 de julio de 2010.

${ }^{27}$ Entrevista inédita realizada por Esther García Soriano a Antoni Duran Barba el 14 de julio de 2010.

${ }^{28}$ Comúnmente denominada copión cinematográfico.

${ }^{29}$ Entrevista inédita realizada por Esther García Soriano a Antoni Duran Barba el 14 de julio de 2010.

${ }^{30}$ No se ha logrado identificar a este ayudante.

${ }^{31}$ García, J. El salto de la muerte. Anotación escrita por García Leoz en la portada del borrador del bloque N¹5 "Danza de la hada". Pamplona: Archivo Real y General de Navarra.

${ }^{32}$ García, J. Tarjeta de visita. Anotación escrita por García Leoz en la primera página sin numerar del bloque $\mathrm{N}^{\circ} 3$ de la partitura manuscrita para orquesta. Pamplona: Archivo Real y General de Navarra.

${ }^{33}$ Entrevista inédita realizada por Esther García Soriano a Antoni Duran Barba el 14 de julio de 2010.

${ }^{34}$ García, J. La fiesta sigue. Anotación escrita por García Leoz en la última hoja sin numerar de los borradores del pasodoble. Pamplona: Archivo Real y General de Navarra.

${ }^{35}$ Roy M. Prendergast explica con detalle estas prácticas en Prendergast, R. M. (1992). Film Music, a Neglected Art: A Critical Study of Music in Films. Nueva York-Londres: W.W. Norton \& Company; 263268.

${ }^{36}$ Entrevista inédita realizada por Esther García Soriano a Antoni Duran Barba el 14 de julio de 2010. 


\section{Referencias Bibliográficas}

A. (1943). Música. Juan Durán Alemany, en Radiocinema, año V, nº 93, 30 de octubre de 1943.

Adorno, T. W. \& Eisler, H. (1947/2007). Composing for the Films. Londres: Continuum.

Alvares, R. \& Arce, J. C. (1996). La armonía que rompe el silencio. Conversaciones con José Nieto. Valladolid: 41 Semana Internacional de Cine.

Anónimo. (1946a). La música en el cine para 1947, en Radiocinema, año VIII, nº 130, 1 de diciembre.

Anónimo. (1946b). Los oficios del cine. El músico. Cómo se hace la partitura de una película. Charla con el maestro Leoz, que ha hecho sesenta, en Primer Plano, año VII, $\mathrm{n}^{\mathrm{o}} 315,27$ de octubre.

Arce, J. (1999). Notas al CD José Nieto dirige la música de Jesús García Leoz. Orquesta Sinfónica de Radio Bratislava.Madrid: Fundación Autor; SGAE; Karonte.

Bodegas, R.; Padrol, J. \& otros (1986). Evolución de la Banda Sonora en España, en Calvo, F. (Coord.). Evolución de la Banda Sonora en España: Carmelo Bernaola. Alcalá de Henares: Festival de Cine de Alcalá de Henares; 15-75.

Carmona, L. M. (2007). La música en el cine español. Madrid: Cacitel.

Celaya, L. (2014). Vida y obra de Jesús García Leoz (1904-1953). Universidad Pública de Navarra. Tesis Doctoral dirigida por Isabel Ostolaza Elizondo y Marcos Andrés Vierge.

Chion, M. (1997). La música en el cine. Barcelona: Paidós.

Colón, C. (1993). Introducción a la historia de la música en el cine. La imagen visitada por la música. Sevilla: Alfar.

Colón, C.; Infante, F. \& Lombardo, M. (1997). Historia y teoría de la música en el cine: presencias afectivas. Sevilla: Alfar.

Cueto, R. (2003). El lenguaje invisible. Entrevistas con compositores del cine español. Madrid: 33 Festival del Cine de Alcalá de Henares, Comunidad de Madrid.

Fernández-Cid, A. (1953). Jesús Leoz. Madrid: Ateneo. 
Galán, D. El cine español de los años cuarenta, en Gubern, R. (Coord.). (2000). Un siglo de cine español. (Cuadernos de la Academia, 1). Madrid: Academia de las Artes y las Ciencias Cinematográficas de España; 113-127.

Huntley, J. (1947). British Film Music. Londres: British Year Books.

Karlin, F. (1994). Listening to Movies. The Films Lover's Guide to Film Music. Nueva York: Schirmer Books.

Lack, R. (1999). La música en el cine. Madrid: Cátedra.

Levy, L. (1948). Music for the Movies. Londres: Sampson Low.

London, K. (1936). Film Music: A Summary of the Characteristics Features of its History, Aesthetics, Technique and Possible Developments. Londres: Faber and Faber.

López, J. (2009). Música y cine en la España del franquismo: el compositor Juan Quintero Muñoz (1903-1980). Universidad de Granada. Tesis doctoral dirigida por Antonio Martín Moreno.

McCarty, C. (1989). The Literature of Film Music, en McCarty, C. (Ed.). (1989). Film Music 1. Nueva York: Garland; ix-3.

Nieto, J. (1996). Música para la imagen. La influencia secreta. Madrid: SGAE.

Pachón, A. (1992). La música en el cine contemporáneo. Badajoz: Diputación de Badajoz.

Padrol, J. (1998). Pentagramas de película: entrevistas a grandes compositores de bandas sonoras. Madrid: Nuer.

Prendergast, R. M. (1992). Film Music, a Neglected Art: A Critical Study of Music in Films. Nueva York-Londres: W.W. Norton \& Company.

Roldán, D. (2004). Fuentes documentales para el estudio de la música en el cine español de los años 40. Universidad Politécnica de Valencia. Tesis doctoral dirigida por Eulalia Adelantado Mateu.

Roldán, D. (2005). La música en el cine español en los primeros años del franquismo, en Olarte, M. (Ed.). La música en los medios audiovisuales. Salamanca: Plaza Universitaria. 467-470.

Romagueira i Ramió, J. (2002). El jazz y sus espejos. Madrid: Ediciones de la Torre.

Sabayenev, L. (1935). Music for the Films: A Handbook for Composers and Conductors. Londres: Pitman and Sons. 
Xalabarder, C. (1997) Enciclopedia de las bandas sonoras. Barcelona: Ediciones B.

Recursos web

Base de datos de películas calificadas del Ministerio de Cultura (España). (www.mou.es/cine/index.html) (10-10-17).

The Film Database. (www.citwf.com) (10-10-17).

The Internet Movie Data Base (IMDB). (www.spanish.imdb.com) (10-10-17). 